\title{
A. ADAMUSCIN
}

\section{INVESTING IN EUROPEAN MARKET REAL PROPERTY THROUGH REITS}

\begin{abstract}
For institutional and private investors, investing in real estate represents an attractive form of the consignment of their money. Real estate provides a regular source of income in the form of the rent from or interest on the credit provided. At the same time, real estate is a good investment instrument, because it provides diversified contributions and security against inflation for investors. In their efforts to diversify risk, investors are expressing growing interest in investing in the whole European Union. The success of Real Estate Investment Trusts (REITS) in the U.S. also opened the door for investing in this market for small investors, which is the reason for the development of this type of investment company in the European arena. One problem concerning the development of European real estate investment funds is the unsolved issue of the harmonization of the legislation and regulatory safety measures, which would enable the creation of a common market for new investment products in Europe.
\end{abstract}

\section{INTRODUCTION}

Real estate funds represent an attractive form of investing in an asset class which is yield stable and low-risk - real estate. Their portfolio consists of various types of real estate or the assets of subjects investing in real estate. Individual real estate funds have various investment strategies. They can have the form of a sector (residential structures, business centers, logistical parks, etc.) or a regional orientation with a precisely delimited area. The income of the real estate funds come from the renting or sale of real estate. Investing in funds helps to make the real estate market more effective by the fact that investors come with a huge packet of money, by which they support building production and thus contribute to the growth in competition of the market.

A real estate fund can invest directly in real estate or indirectly by means of real estate companies in individual real estate projects.
A limiting factor is the liquidity (1-3 years), which cannot be based on a daily base; as a consequence, the investment horizon for the investor does not have a short-run character. Investors can also invest in real estate stock funds, which belong to the sector funds of participation certificates; they are focused on companies which do business in the area of real estate. These real estate share funds react to decreases in share markets. Additionally, there is also a currency risk, because they invest abroad, which is connected with security against a decrease (increase) in the value of the relevant currency, through which a decrease in profitability can occur [1].

\section{REITS IN THE UNITED STATES}

In 1960, the United States Congress passed a law which laid the foundations for a new type of company, the so-called real estate 
investment trust (REIT), with a view to making the investments in commercial real estate available for small investors. At that time, hardly anyone believed that after a few decades, it would be one of the favorite investment instruments not only of private investors but also of pension funds, insurance companies and investment funds. It took awhile for REITs to establish themselves as investment vehicles; moreover, they came through several crises, the biggest of which was probably during a period of high interest rates in the first half of the 1970s. While this business in the 1960s was transacted with only ten real estate trusts, which administered real estate valued at 200 million dollars, today there are almost 136 REITs on the stock markets in the USA with assets valued at more than 200 billion dollars (NAREIT, 12/31/2008). These REITs are registered with the Securities and Exchange Commission in the USA, and the majority do business on one of the most significant stock markets - the New York Stock Exchange (NYSE). There are also many REITs that are not traded on a stock exchange. Some REITs invest in a variety of property types, including shopping centers, apartments, warehouses, office buildings and hotels. Other REITs specialize in one property type. For example, health care REITs specialize in health care facilities, including acute care, rehabilitation and psychiatric hospitals, medical office buildings, nursing homes and assisted living centers [2,3].

A real estate investment trust (REIT) is a company which owns, rents, administers and invests in real estate and does not pay income tax on the gains resulting from this activity. But the advantage in the form of a tax exemption is conditioned by the fulfillment of several criteria. The main one is the obligatory distribution of at least $90 \%$ of the gain in the form of dividends. This enables real estate trusts to achieve a high and mainly stable dividend yield. In addition to the obligatory payment of any dividends according to the Internal Revenue Code, a REIT must fulfill some other conditions, too. These are $[4,5]$ :

- Be structured as a corporation, trust, or association

- Be managed by a board of directors or trustees

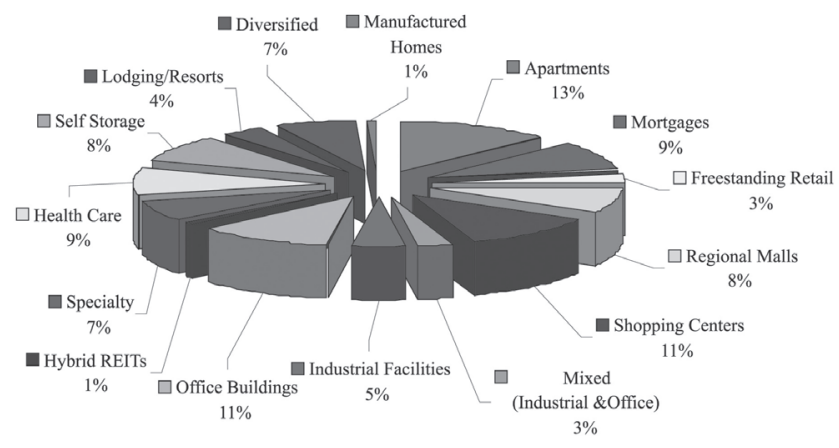

Fig. 1 REITs Invest In All Property Types (as of Dec. 31, 2008) [2]
- Have transferable shares or transferable certificates of interest

- Otherwise be taxable as a domestic corporation

- Not be a financial institution or an insurance company

- Be jointly owned by 100 persons or more

- Have 95 percent of its income derived from dividends, interest, and property income

- Pay annually at least 90 percent of its taxable income in the form of shareholder dividends

- No more than $50 \%$ of the shares can be held by five or fewer individuals during the last half of each taxable year (5/50 rule)

- At least $75 \%$ of the total investment assets must be in real estate

- Derive at least $75 \%$ of its gross income from rents or mortgage interest

- No more than $20 \%$ of its assets may consist of stocks in taxable REIT subsidiaries

\section{Three Types of REITs}

REITs can be broken down into three categories: equity REITs, mortgage REITs and hybrid REITs [3, 5].

1. Equity REITs - These trusts own and/or rent properties and collect the rental income, dividends and capital gains from sales of property. The triple sources of income make this type very popular.

2. Mortgage REITs - These trusts carry a greater risk because of their exposure to changes in interest rates. If interest rates rise, then the value of mortgage REITs can drop substantially.

3. Hybrid REITs - These instruments combine the first two categories. They can be either open or close-ended (similar to open and close-ended mutual funds), have a finite or indefinite life and invest in either a single group of projects or multiple groups.

\section{THE REIT FROM A GLOBAL PERSPECTIVE}

REITs as an asset class already have a long history in a number of countries. The United States introduced REITs in the late 1960s, although their reputation as a successful investment vehicle was not achieved until the 1990s. Other REIT structures can be found in the Netherlands (BI), Australia (Listed Property Trust), Canada (REIT), Belgium (SICAFI), Japan (J-REIT), Korea (K-REIT/CR-REIT), Singapore (S-REIT), Hong Kong (H-REIT), and France (SIIC). Countries with investment vehicles whose structures are similar to those of REITs are New Zealand, South Africa, Italy, Luxembourg and Spain. And like Germany, Great Britain also enacted REIT legislation effective from January 2007, by creating the UK REIT or Property Investment Fund (PIF) [3]. 
These initiatives were usually motivated by an effort to create effective and liquid means of investing in property, mainly for smaller investors, and which would simultaneously contribute to the increasing flow of money to the building industry.

\section{TAXATION AND LEGISLATION OF REITS}

A top benefit of REITs is the avoidance of double taxation, first on the company level (income from the rent) and then on the shareholder level (taxation of dividends). The non-taxation of dividends puts a shareholder in the position of an investor who owns a portfolio. As the financial flows from the rent will be taxed as the only type of income, the same income conditions are created for direct investors and shareholders. Double taxation is quite a common problem in many countries of the world. Double taxation is aimed at acquiring higher revenues for a state's budget; at the same time it means a reduction in often-unearned gains for shareholders, which can be a problem mainly for heirs of considerable financial resources, who live only on dividends and perform no work for the country of which they are citizens.

It is true that the taxation of dividends can also discourage investors from investing on the stock market. In Slovakia, double taxation was cancelled by the Slovak government in an effort to attract foreign investment.

Nowadays, 13 of the 27 EU membership countries permit a certain form of tax transparency for real estate, but the conditions of taxation are substantially different in the various countries. Real estate agencies must face a great variety of legislative and regulatory requirements, investment rules and financial restrictions. When making international comparisons, it cannot be denied that European legislation, which governs and adjusts the conditions for the functioning of the real estate sector, are a mixture of everything. This fact slows down the process of cash flows in Europe and discriminates against investors in those European countries in which legislation supporting investment in real estate has not yet been established [6]. Such a situation is unfavorable mainly in comparison to the USA. In the USA REITs represent growing companies, which create still stronger cash flows to the real estate markets. REITs are then used by both private and public investors for the purpose of gaining access to real estate assets in a liquid manner.

Investments in real estate by means of shares which are quoted on the stock market have risen significantly over the last 20 years. Today investors still prefer indirect investment in real estate more often. Investments in real estate represent a preferred means of investment in real estate mainly for international investors (and mainly for pension funds). For example, the British pension fund Hermes has $80 \%$ of its foreign investments in real estate in the form of shares of quoted real estate companies on the stock market in its portfolio. Quoted real estate companies are important not only for pension funds but also for small investors, as their low amount of resources to invest prevents them from access to the markets. The purchase of shares of real estate agencies also enables access to real estate portfolios for small investors [6].

In every country which has a fiscally transparent structure, the tax exemption is guaranteed, which enables investors to avoid double income taxation. Without the tax exemption the income from the rent of real estate is taxed first on the company level and then on the shareholders. In this case the shareholder gets into a disadvantageous position in relation to an investor who owns a real estate portfolio directly, as the flow from the rent is taxed only as income. A legal entity with an income tax exemption also stimulates indirect investments in real estate.

REIT legislation is similar in a way to mutual fund legislation. Private investors can buy shares directly or indirectly through mutual funds. The indirect method has a number of advantages, insofar as there is no double taxation. Shareholding by means of mutual funds represents a standard way for private investors to gain access to the stock market.

A citizen of the European Union can directly invest his resources in real estate; in this case only his income is taxed. He can also invest in an indirect way by means of a domestic real estate company or a domestic REIT. In the first case the real estate's cash flow is taxed first on the company level and then on the investor's level again. Investment by means of REITs enables the avoidance of this double taxation, as it is tax-free on the company level. But if a REIT invests in real estate in another member country, the REIT is then taxed in the other EU member country; therefore, a citizen of the European Union cannot invest in another EU member country without avoiding double taxation of the real estate [7].

The next way of investing financial resources in the real estate market is by means of pension or mutual funds or eventually through insurance companies; however, benefits gained from these providers are taxed as income and therefore also subject to double taxation. So nowadays, if anyone wants to invest in real estate in another country, it is highly probable that he will be subject to double taxation.

Thirteen countries of the European Union have established transparent REIT regimes, but that does not mean that real estate companies quoted on the stock market have the same access to the dividend policy. The majority of them are obliged to split their profits $80-100 \%$ to their shareholders; in the case of the French SICOM it is at least $50 \%$ of the profits, but in Greece, only $35 \%$. In Poland, Malta and Spain there is no such requirement. The stated transparent instruments are often limited by financial, and eventually, the operating restrictions and requirements of the 


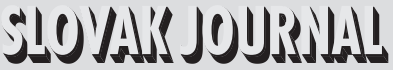 \\ 1)

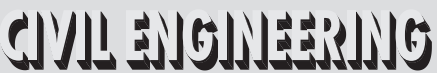

2010/1 PAGES $31-42$

Fig. 2 Structures for Property Companies Listed in the EU

\begin{tabular}{|c|c|c|c|}
\hline Country & Structure name & Year & Full structure name \\
\hline Austria* & ImmoInvFG & 2003 & Immobilien Investmentfondsgesetz \\
\hline Belgium & Sicafi / Bevak & 1995 & Société d'Investissement à Capital Fixe Immobilière \\
\hline Bulgaria & REIT (SPIE) & 2003 & Special Purpose Investment Entity \\
\hline \multicolumn{4}{|l|}{ Cyprus } \\
\hline Czech Republic & & 2006 & \\
\hline \multicolumn{4}{|l|}{ Denmark } \\
\hline \multicolumn{4}{|l|}{ Estonia } \\
\hline \multicolumn{4}{|l|}{ Finland*** } \\
\hline France & SIIC & 2003 & Société d'Investissements Immobiliers Cotées \\
\hline Germany & G-REIT & 2007 & German Real Estate Investment Trust \\
\hline Greece & REIC & 1999 & Real Estate Investment Company \\
\hline \multicolumn{4}{|l|}{ Hungary } \\
\hline \multicolumn{4}{|l|}{ Ireland } \\
\hline Italy**/*** & FII & 1994 & Fondi di Investimento Immobiliare \\
\hline \multicolumn{4}{|l|}{ Latvia } \\
\hline \multicolumn{4}{|l|}{ Lithuania } \\
\hline Luxembourg**** & SICAV & 2002 & Société d'Investissement à Capital Variable \\
\hline Malta** & PIF & 1994 & Professional Investor Fund \\
\hline The Netherlands & FBI & $1969 / 2007$ & Fiscale Beleggingsinstelling \\
\hline Poland** & REIF & 2004 & Real Estate Investment Fund \\
\hline \multicolumn{4}{|l|}{ Portugal } \\
\hline \multicolumn{4}{|l|}{ Romania } \\
\hline \multicolumn{4}{|l|}{ Slovakia } \\
\hline \multicolumn{4}{|l|}{ Slovenia } \\
\hline Spain** & REIF/REIC & 2003 & Fondos/Sociedades de Inversion Inmobiliaria \\
\hline \multicolumn{4}{|l|}{ Sweden } \\
\hline United Kingdom & UK-REIT & 2007 & UK Real Estate Investment Trust \\
\hline
\end{tabular}

Note: In this figure, the various tax-transparent structures in the EU27 countries are listed, including the year of introduction of the

structure. Blank boxes indicate that property companies are treated as ordinary corporations.

Sources: Ernst and Young (2006), Op 't Veld (2007).

* no special REIT legislation, but under Austria's open-ended structure, funds do not pay corporate tax.

** no special REIT legislation, but the current structure is REIT-like

*** currently no REIT structure, but steps are being undertaken to implement one

**** no REIT structure, but beneficial (corporate) tax treatment 
shareholders. So all of these companies are regulated and differ from each other; as a consequence, there is a considerable variety in the stated companies as well as in their chaotic arrangements [8].

Operating restrictions mainly apply to rules for diversification, permits or bans on dealing in real estate development, portfolio business activities and also specifications of under what circumstances it is possible to invest in REITs.

The common aim of the legal restrictions and requirements is to guarantee that real estate companies will operate as low-risk passive investors who administer portfolios for their clients. But this aim is dealt with in the legislation of different countries in very different ways. In some countries, for example, a restriction is defined as to the share of one's resources expressed in a percentage that can be invested in a certain type of real estate, but the stated share can differ in different countries and, in some of them, it is even missing.

The operating restrictions for development activities are different in various countries $[7,9]$ :

- No development activities are permitted (for example, Germany)

- Only reconstruction is permitted or eventually, the partial enlargement of existing real estate

- Development is permitted, but only within an in-dependent company which pays taxes (for example, the Netherlands)

- All types of development activities are permitted (certain restrictions exist in the Netherlands, but no restrictions exist in Poland and Austria).

REITs mainly serve as passive investment instruments, which should provide investors with a relatively stable return. As a high share of the funding of real estate from credit resources increases the risk for shareholders, regulatory institutions restrict the funding of credit. For example, the Spanish government only permits $10 \%$ lending in REIC (real estate investment companies); the British have no restrictions with the exception of an obligation to fulfill the requirements of a test for meeting the interest rate. But the majority of the countries restrict the credit funding to $40-60 \%$ of the value of the real estate.

When the credit costs are not higher than the yield from the real estate, lending is also profitable for shareholders. In this case restricting the credit activity limits the opportunities of REITs to grow and develop.

Legislation also deals in a different way with the issue of the restrictions per number of shareholders and the amount of shares which they can own. In other places quotation on the stock market is also obligatory, which makes access to capital easier. But, unfortunately, the stock market valuates a company not always according to its real value, which comes from the portfolio of the real estate owned. Then a lower stock market valuation can lead to a lack of interest on the part of the shareholders.

\section{PROBLEMS OF THE CURRENT INSTITUTIONAL STRUCTURE IN THE EUROPEAN UNION}

Various legislative restrictions in different countries of the EU lead to different game rules for real estate companies and investors, which also means that investment opportunities vary in different countries. As a result, there is a deformation of a competitive environment at the level of the Community.

For example, while the withholding tax is $22 \%$ in Great Britain, it is zero in Luxembourg. Often the citizens of a certain country do not need to pay such taxes, while the citizens of another country have an obligation to do so. While in some countries there are the same tax rates for withholding and from increases in capital, in other countries these rates differ $[6,8]$.

The disunity of the existing legislation is therefore a barrier to specialization of real estate companies. Actually, one of the strategies of real estate companies is diversification. Real estate companies can diversify their strategies in more than one type of real estate (examples: residential, business, office and industrial). More specialized types of real estate include housing for senior citizens, shopping-related real estate, hotels, self-storage and even private prisons. Even deeper forms of specialization include businesses on the most prestigious streets, regional business centers and so on. It is a possible to diversify real estate from a geographic point of view and in more than one country.

The majority of European REITs have quite diversified portfolios and invest in many types of real estate. Office and business spaces are preferred; international diversification is rarer.

On the other hand, in the USA, real estate companies as a rule focus on one sector of the real estate market, which is, however, more geographically diversified. In the USA there is no problem diversifying the investments in individual states. In this way savings from a variety of transactions and specializations is often achieved. American REITs are usually very specialized. For example, they do not invest in all commercial real estate, but only in a chosen segment of this market. Larger companies are then better personally provided, and they acquire real estate more easily and secure growth in their rents. Some segments of this market did not exist 20 years ago, for example, the self-storage market, real estate used for social purposes such as old people's homes, housing for senior citizens and REITs for the health service.

Experience shows that REITs are often able to administer old people's homes and medical institutions better than the public sector 
or hospitals. For example, in the area of housing for senior citizens, three American REITs operate: Chartwell Seniors Housing, Sunrise Senior Living and the Senior Housing Real Estate Trust. Ten health REITs administer hospitals, office buildings, social care institutions and others. The majority of these REITs focus on the acquisition of buildings, but they do not deal with the development process [6].

Significant areas of the business of REITs are student hostels. For example, American Campus Communities, which was the first REIT of this type in the USA, administers 42 real estate properties with 26,400 beds and offers leasing and administrative services for 57 other real estate properties containing about 35,700 beds. In the USA several REITs have been created in this area. In the USA, GMH Communities Trust and Education Realty Trust also operate in the area of the administration of student hostels. All three companies are quoted on the stock market.

The fragmented market keeps institutional investors from entering this market in Europe. In Europe student hostels have traditionally been administered by universities, which is still a bigger problem; therefore, smaller companies often provide students with rooms, but the number of rooms is not high enough, their quality is low, and their prices are high. In addition, the rent in student's hostels is often up to $30 \%$ more expensive than in conventional flats [7].

Expert studies carried out in the USA showed that REITs have a higher degree of efficiency in most cases, as a result of the savings from the range of transactions and as a result of the spread of their portfolios. As a consequence, it is probable that they will achieve higher profits and lower costs, which leads to a direct relation between the profitability of a company and the size of the company. For example, in larger REITs a higher growth of occupancy of the real estate and a higher growth of incomes is achieved in comparison to hotels on private property. The higher efficiency of REITs is partially a consequence of better acquisition decisions.

The most important reason for savings from the range of transactions in American REITs is investment in one type of real estate and diversification of this type of real estate in different regions. In Europe diversification according to various types of real estate is more common. According to older theories, this kind of diversification should have permitted a lower correlation among the cash flows, and so a decrease in the investment risk occurs and also a decrease in investment costs.

But it was determined later that this type of investment leads to a decrease in the transparency of operations and to an increased asymmetry in information; this actually cancels out all of the benefits of such a diversification. In companies which have a higher diversification rate, on the one hand, higher income is reached on the level of individual projects but, on the other hand, this income is accompanied by higher operating, administrative and interest costs. The reason why European companies mainly focus on the diversification of more types and not on geographical diversification is the lack of common legislation in the EU, which influences the efficiency of the European REITs negatively in comparison to the American ones. Companies which have a pan-European diversification strategy must face a number of rules and regulations, which negatively influence their performance. The American model of the organization of the REIT "industry" also seems to be optimal for Europe, provided, however that the legislative obstructions are eliminated.

The prospective establishment of REITs in the European Union, which would be based on unified legislative rules, could bring about a more effective allocation of capital flows in the real estate sector, which means that capital will flow to those areas which are funded insufficiently. The stated fact is in accordance with the principles of market efficiency. These principles are in conflict with the current situation, which is obstructing the effective allocation of capital. There are obstacles to the free flow of capital in Europe, so money does not flow to the places where the best business opportunities are.

Furthermore, real estate companies which operate in European conditions have problems achieving savings from their range. The opportunities for international diversification are limited, as not all of the membership countries have a similar method of income tax exemption (which means the avoidance of double taxation). Additionally, the insufficiency of a tax-transparent structure leads to a decrease in the value of real estate companies on the stock market. It is interesting to compare the amount of a company's real estate in the USA and in Europe. While in Europe $70 \%$ of business subjects are owners of commercial real estate in which they have a residence, in the USA it is only $30 \%$ [7].

Many companies in the West are more interested in renting real estate property instead of owning it. The renting of real estate decreases their capital drain and increases a business's flexibility. Usually, after a real estate property is sold and subsequently rented, the rate of return to the shareholders increases. There is a negative relation between commercial real estate and the efficiency of their shares, which is adjusted by the risk.

With the selling of real estate in companies which own more of it, the capital structure is improved, which makes it possible to borrow resources under more favorable conditions for their repayment. A more effective financial structure enables a more effective allocation of financial resources to the core business of the company, as a smaller amount of capital is bound up in real estate. Leasing of commercial real estate potentially leads to cost savings, as there is an effort to use it more effectively; on this basis higher gains are achieved. The main impulse for the selling of commercial real estate is the availability of institutional capital, by which it is possible to gain real estate assets. 
While the availability of capital is not a problem in itself, the structure of a REIT is the most effective way of securing capital flow to real estate markets. It is used for securitization of real estate assets and acquisition of a shareholder's capital from the capital markets, as has happened to a great extent in the USA. A common pan-European REIT structure could support companies with the opportunity to unite real estate from various geographical areas into a common real estate investment company, which could achieve an adequate size. It is just the size of an investment company that enables it to use the contributions from specialization and the savings from a range of operations.

As a consequence of the removal of real estate assets and the smaller amount of capital which is bound up in fixed assets, companies could mainly focus their attention on their core business. This fact will support an ongoing trend, which is leading to higher economic efficiency in European companies.

\section{Stability of real estate markets}

The currently insufficient development of REITs in Europe is unfavorable from the point of view of the stability of the real estate markets from four points of view $[6,8]$ :

1. In countries where REIT structures are absent, companies are trying acquire other debt, as the interest is an allowable tax deduction. As a consequence, the security of local real estate markets is decreasing. The high degree of the indebtedness of real estate markets can be very dangerous as the experience from the American mortgage crisis is showing us.

2. REITs bring the potential for a geographical and international diversification of the real estate markets in Europe. As the research in Europe shows, the degree of correlation among the flat markets in Europe is very low, which means that geographical diversification is the way to decrease the risk of portfolio investments in these markets substantially.

3. REITs are required to pay out $90 \%$ of their gains to shareholders. That is the reason why managers must acquire the resources for funding new acquisitions by financial institutions and investors. This leads to the fact that their activity is often controlled by external subjects (banks and investors), thanks to which the conflict between the interests of shareholders and managers is decreasing. The restrictive framework for the operating of REITs leads to the administration of the quality of a REIT by the owners and other interest groups. Small and medium-sized shareholders mainly profit from the stated situation, as their interests are better respected, which increases the security of the real estate markets.

The establishment of REITs is also probably a way to decrease the number of tax havens, on the territory of which real estate companies are sometimes created. The operating of real estate investment companies in tax havens weakens their administration and financial supervision. The lack of transparency of these real estate investment companies leads to a higher number of problems with their supervision and administration. Real estate companies in tax havens are mostly operated externally, which often leads to the growth of capital in blind pools. Blind pools seldom result in an effective return on investments; their functioning is controlled by shareholders with difficulty.

\section{REQUIREMENTS FOR A PAN-EUROPEAN REITS}

The requirements for an EU REIT must be simple and minimized wherever possible. A powerful indicator of a REIT structure is an obligatory payout of net income, which was originally one of the aims of REITs - to secure a taxable income which is strong enough by means of the taxation of gains on the shareholder level. Currently, the payment duties are only accompanied by trivial agency problems. According to the traditional agency hypothesis, conflicts of interest between shareholders and managers occur as a result of different opinions on the investment horizon, the tendency to take over a sovereign rule, and the effort to avoid risk by some managers. The main problem, which is typical of the agency hypothesis, is too much cash in the hands of managers, the so-called problem of free cash flow. As a consequence of a REIT's status, whereby the tax exemption and the obligation to pay out most of the net income to the shareholders arises, the conflict of interest between the managers of a real estate company and its shareholders is minimized [6].

The obligation to pay out most of the net income to shareholders leads to the necessity to achieve the development of financial resources on the capital markets and in the financial institutions, thereby getting REITs under economic control from the outside more often. At the same time, the degree of asymmetry of the information available to managers and shareholders decreases; therefore, a further reduction of the agency problem occurs. The structures of the administration and supervision of the company are focused on monitoring of the managers' behavior and minimizing the agency problem.

In the last decade European countries have published regulations which deal with the practice of the administration and supervision of a company. In addition, some regimes which are similar to REITs in the EU member countries have specific requirements which concern the structure of the administration and supervision of a company by real estate companies.

The main problem in the administration and supervision of companies in the process of the creation of European REITs is 
whether real estate companies should be managed internally or externally. Many real estate companies in Europe are managed externally, which contrasts with the practice in the USA, where this type of management in a real estate company has practically disappeared. Current American REITs which are managed internally are much more efficient than externally managed REITs.

In some countries, for example, in the USA, there is a requirement that REITs must have at least 100 shareholders, while the share ownership of the five largest shareholders must not exceed 50\% of the shareholders' REIT capital. These restrictions have been established to prevent big shareholders from getting a hold of the property of the small shareholders. This state, however, simultaneously supports splitting the property, which also brings some disadvantages. Therefore expert opinion is that no restrictions on shareholding should be established [6].

Out of the 13 countries of the EU which have a tax-transparent regime, only six require the obligatory quotation of companies on the stock market. Although this can be good for the liquidity of shares, it is doubtful whether such rules should be established.

Long-term experience from the USA and the Netherlands demonstrates that quoted and unquoted REITs can mutually coexist in a good way. In fact, companies can change their status and follow developments in the market. Sometimes it is more advantageous to have a company quoted on the stock market, while other times it is disadvantageous if it brings increased costs which are not compensated for by higher contributions. In such a case it is appropriate to have a company unquoted from the stock market. The creation of pan-European REITs should require no quotation on the stock market.

Existing restrictions in Europe concern diversification, the development of the business, and restrictions on assets. They have mainly been established to obstruct the possibility to realize real estate investments which are very risky. However, such restrictions can bring their negatives, too. For example, restrictions on assets limit the opportunity of gaining new managerial experience for managers of REITs, which obstructs their learning from other markets and other assets [8].

The academic literature mainly discusses the question of whether companies should diversify, or whether shareholders should diversify their assets. It is recommended that shareholders diversify, but REITs should specialize in a certain segment of the real estate market. In this way higher yields are reached.

Also, the restrictions on business and development lack rationale. It is not appropriate to restrict development. The combination of development and business leads to an increase in value. Naturally, it is necessary to establish game rules, so that there is a difference between pure developers and REITs. The development activities of REITs must be taxed on the basis of the same regime as the development companies. It is done in this way in the Netherlands and Great Britain. The exception is real estate if a REIT in Great Britain has property built for the purpose of renting it and gains income from the rent. But if a British company sells this real estate within three years from the date its construction is completed, it will have to pay income tax as a legal entity similarly to a developer.

The practice of some countries often contains restrictions on liquid means. Restrictions of this type do not make much sense within the pan-European REITs either and mainly in the present, when European real estate markets are still more transparent and equipped with an army of analysts, financial reporters, researchers and consultants, who monitor these markets in detail.

Instead of restricting managers' behavior and restricting investments, it is recommended to establish strong internal monitoring mechanisms in EU REITs, which would reward top managers of a REIT for their efficiency.

The British experience shows that the best harmonization of managers and shareholders is achieved through the top managers' ownership of shares. The ownership of shares by the managers positively affects the value of a REIT company. Having a sufficient number of external directors on a managing board is also recommended, and the functions of the chairperson of the managing board and the president of the company should be separate.

It is unclear whether to prefer open-end or closed-end trusts for future pan-European funds. These forms differ, mainly from the viewpoint of the fixity of the money invested. While a shareholder can withdraw money from an open-end trust whenever he wishes if he accepts the current exchange rate of the share, he cannot get it from a closed-end trust sooner than the statute of the fund allows. The administrators of closed-end trusts must also publish the values of shares with a lower periodicity than those of open-end ones [7]. In the past real estate companies in the Netherlands and Australia were characterized as open-end funds. Within such a structure investors could buy or sell shares from real estate companies whenever they wanted. The main advantage for investors was the high liquidity and low volatility of the yields.

The final price of open-end real estate companies is counted on the basis of the net value of the assets, plus the payment for the offer, which is usually $5 \%$. The net value of the asset is stipulated on the basis of the assessment of the current market value of all the assets which the company has, minus its obligations, and divided by the number of shares issued. Although the majority of the assets which are a part of the property of real estate companies is characterized as real estate, these companies also often own liquid assets, to which, for example, the shares of other real estate companies or financial market instruments belong. The assessment of the value of the latter two assets is relatively simple, as the market price information is available in real time as a rule. This is not typical at all for a real 


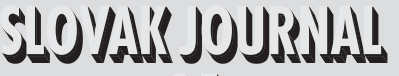 \\ os

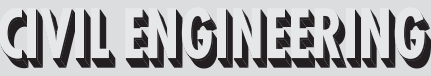

2010/1 PAGES $31-42$

Fig. 3 Proposals for EU REITs

\begin{tabular}{|l|l|}
\hline Restrictions and Requirements & Motivation \\
\hline Tax exempt & $\begin{array}{l}\text { Avoids double taxation of rental income and creates level playing field with direct real } \\
\text { estate ownership. }\end{array}$ \\
\hline Internally managed & $\begin{array}{l}\text { Guarantees ultimate tax payment and is effective government mechanism, mitigating } \\
\text { agency problems. }\end{array}$ \\
\hline Operational restrictions & $\begin{array}{l}\text { Better governance and alignment of interests of managers and shareholders; better } \\
\text { performance, more shareholder value. }\end{array}$ \\
\hline development allowed, but taxed & $\begin{array}{l}\text { Development can create shareholder value, but maintain level playing field with pure } \\
\text { taxed - developers. }\end{array}$ \\
\hline no diversification requirements & Investors can diversify themselves and do not need extra protection. \\
\hline no asset restrictions & Government should not interfere with investment strategy. \\
\hline No leverage restrictions & $\begin{array}{l}\text { Restrictions put REITs at disadvantage to other property investors. Management } \\
\text { should decide on optimal financing. }\end{array}$ \\
\hline No mandatory listing & Listing not always beneficial. Management should decide on optimal financing. \\
\hline No ownership requirements & Better for governance. \\
\hline $\begin{array}{l}\text { Withholding tax equal for domestic investors } \\
\text { and those from other EU member states }\end{array}$ & Creates level playing field for all EU investors. \\
\hline Closed-ended structure & $\begin{array}{l}\text { Open-ended structure fundamentally unstable. Closed-ended structure creates more } \\
\text { shareholder value. }\end{array}$ \\
\hline
\end{tabular}

Note: This figure provides a blueprint of an EU REIT. The restrictions and requirements are based on the existing academic literature and empirical evidence presented in this report.

Source: Eichholtz, Kok

estate portfolio. An accurate assessment of the value of real estate is very difficult. Even the use of independent experts does not solve the problem.

The valuation of real estate suffers as a consequence of smoothing and lagging and the fact that the valuators tend to influence themselves by looking into the past. This leads to a difference between the actual prices and the values counted by the valuators, mainly from the viewpoint of the volatility and the average yields [7].

As buildings are rarely sold, time shifting occurs when assessing true real value of real estate. It is not possible to assess the value of real estate by direct monitoring of the market. The smoothing occurs as a result of the fact that the valuators use old information in new assessments. If they do this systematically, the price development will be too smooth, and the volatility will be set artificially low. In the event there is a great deal of vagueness about the new information, the valuators of real estate tend to rely on the old data which was used in the previous assessment reports or, what is even worse, they directly use the data which was stated in those reports.
The experience with open structures in the Netherlands and Australia illustrates the difficulties of assessing and shows the negative results to which it can lead. Quoted real estate companies on the stock market overcame a strong crisis and were subsequently transformed into closed-end funds.

An open-end regime enables the funding of illiquid assets by means of the shareholders' capital, but it is possible to convert them into money whenever it is desired. If the real estate markets work smoothly on the whole, such a regime does not create any problems. However, if there is a decrease on the markets, an open-end regime can result in an economic disaster. Based on the facts stated it is recommended that EU REITs be closed-end funds.

\section{INVESTING IN REAL ESTATE IN SLOVAKIA}

In Slovakia we can invest in real estate as of from 1 May 2006, when the amendment to the Act on Collective Investment came into force. The establishment of these funds, which invest in real estate, 
has been forced by the demands of asset management administrators and investors. Based on this fact, the Ministry of Finance prepared a legal regulation which expanded investment options. At the beginning the asset management companies were taking a cautious approach to the new investment option, because they were not experienced enough and also worried about gaps in the law, which the amendment to the Act on Collective Investment did not cover. The administrators mainly pointed out the fact that only direct investments in real estate had to dominate in a real estate fund portfolio and that it was not possible to flexibly invest in any stocks (for example, in shares of development or building companies or in the standard debt instruments which serve to fund real estate projects), of which the yield is derived from the development of real estate prices, which is important for a fund that would also like to invest abroad. This would manage to increase the liquidity of a real estate fund, and the investment risk would simultaneously spread in a more positive way. A fund could invest in a company in the real estate market which owns, rents or administers a building, but only in such a company which administers no more than three real estate items or has an interest in another real estate company, and it must inform the asset managers about its real estate once a month. The problem was also the minimum entry $(40,000 €)$, which was considered to be exorbitant by the administrative companies. In the end the law reduced the minimal investment to $3,000 €$.

In May 2007, after the passing of the amendment to the Act on Collective Investment for real estate funds, the rules were changed. The amendment enabled real estate funds to buy financial instruments (such as shares, bonds, unit trusts, and other instruments related to the real estate market), of which the yield is directly dependent on developments in the real estate market, and it cancelled the minimal investment of $3,000 €(100,000$ crowns $)$. Also, the opportunity was added for a real estate agency in which a real estate fund can be a shareholder to engage in building construction activity [10].

\section{Special real estate funds}

Special real estate funds invest their assets directly in real estate, capital participations in real estate agencies or other assets which are closely connected with the real estate market. The riskiness of these trusts is a little bit higher than that of bond funds, whereas the real estate market also has a cyclical character, and it is therefore necessary to count on an investment horizon which is similar to that of the share funds of 5 to 7 years.

\section{Legislative conditions for investment}

A special real estate fund (SREF) can be created as an open-end unit trust or a closed-end unit trust on the basis of permission from the National Bank of Slovakia (NBS). The unit trust is created by an administrative company which issues participation certificates [11].

- An open-end unit trust is kept for an uncertain period of time, and one of its shareholders has the right to have the participation certificates paid out from the property of this trust anytime at his request. The advantage of investment in an open-end trust is quick access to the money invested. But this type of investment is less profitable for a shareholder in the short run.

- A closed-end unit trust is administered for a certain time, and the shareholder has no right to have the participation certificates paid out from the property of this trust at his request before the expiry of a given period of time. After the expiry of the period for which the closed-end trust was established, two events can occur: either it transforms to an open-end trust or the shareholders are paid out the current price of the shares. The price includes the initial deposit and its valorization. The valorization is decreased by the yields of the participation certificates of investment and deposit accounts, which are paid out regularly every year during the period of the conclusion of the fund.

The property of an SREF can only be invested in real estate, including the fixtures, for the purposes of their administration and sale (direct investments) and in capital participations in real estate companies (indirect investments). For the purpose of administration real estate which brings a regular and long-term yield on behalf of the property of the SREF and the price of which can be set by the yield method can be included in the property of the SREF. For sale purposes real estate which is able to bring a benefit from the sale and the price of which can be set by a comparative method can be used.

The statute of a SREF must include the appellation of the state or residence of the real estate companies in the area where the real estate is situated in which it is intended to invest. The statute must also include the maximum limit of the investment.

The investment in an SREF is a long-run investment with a lower liquidity than the ones other investment instruments have. Therefore, the law provides a year for administrative companies to pay out the returned fund shares to their clients.

Liquid assets (deposits, bonds, bills of credit, and participation certificates issued by an open-end unit trust) must comprise at least $10 \%$ of the fund assets.

The value of the real estate which is acquired as property in a special real estate unit trust must not exceed $20 \%$ of the value of the property in the special real estate unit trust on the date of the completion of the real estate purchase contract or real estate sale contract.

The total value of the real estate items which cannot be valued by the yield method must not exceed $25 \%$ of the value of the property 
in the special real estate unit trust. Also, the value of the real estate which is in the property of a real estate company is counted in the stated limit.

An administrative company can, with regard to the property in an SREF:

- acquire real estate for a price which is more than $5 \%$ higher than the value stated by an expert

- sell real estate for a price which is more than 5\% lower than the value stated by an expert only with the preceding approval of the depositary

The condition for the award of the preceding approval of a depositary is the rationale for such an acquisition or such a sale of real estate. For a property in an SREF an asset management company must not acquire real estate from the property of:

- the administrative company which administers this SREF

- its depositary

- any person from a group with close connections to which a shareholder with a qualified share in the administrative company belongs. The approval of a depositary is required for the acquisition or sale of real estate from an SREF

A real estate agency is a joint-stock company or a foreign trade company, and the subject of its enterprise is the acquisition of real estate including its fixtures, the construction of real estate, the reconstruction of real estate, the administration and rent or sale of real estate. A real estate company can also invest in deposits, participation certificates issued by an open-end unit trust, a European fund or a foreign subject of a collective investment, bills of credit, and bonds which have a payable period of no longer than three years. The value of a capital participation in the property of an SREF during the period of its acquisition in a real estate company can comprise no more than $30 \%$ of the value of the fund's property. A real estate company must not sign a silent partnership agreement.

Each piece of real estate in the property of an SREF must be valuated at least once a year by two independent experts according to the law. One of the experts can be nominated by the administrative company which administers the SREF and the second one by a depositary. The expert report must not be dated back more than three months from the date of the completion of the real estate purchase contract or the real estate sale contract. A real estate item is valuated by the comparative or yield method.

The total amount of all the credits and loans received by an administrative company from the property in an SREF must not exceed $50 \%$ of the value of the property in a special real estate unit trust $[10,11]$.

Slovak real estate funds are mutual investment funds with portfolios consisting of property shares or commercial real estate such as office space, logistical centers, retail centers, residential buildings and hotels. These funds can be open or closed-end mutual funds. The first special real estate fund on the Slovak real estate market was created by the Investicna and Dochodkova Company, which got a license from the National Bank of Slovakia in November 2006.

Some Slovak real estate funds have been less affected by developments on the global real estate markets, and some have not been affected at all. The less affected are obviously special funds that either invested in real estate locally or kept the funds in their current account or invested in short-term securities, as they were still looking for suitable real estate or were better able to predict developments on global markets [10].

\section{CONCLUSION}

Although quite a lot of changes have been made in the area of the integration of European countries since the Community arose, experience shows that there are still a few barriers left which obstruct the free flow of capital. The development of a common European real estate market requires, among other thing, the development of pan-European REITs, which would operate on the basis of unified European legislation. In this way, the efficiency of the functioning of the real estate markets as well as the companies and the public sector which use real estate would certainly increase. By drawing up the relevant regulations it is possible to use the experience of the countries in which this type of institution is very well developed.

The article was written within the scientific-research grant project no. 1/0456/09 Strategic property management in the conditions of globalization. 


\section{REFERENCES}

[1] Chovancova, B. - Kabilova, N. (2008). Investície do nehnutel'nosti verzus fondy (Investments in real property versus funds). Investor [Online] [Cit. 2008-12-10]. Available on: http://investor.hnonline.sk/c1-24936080-investicie-donehnutelnosti-verzus-fondy (in Slovak).

[2] NAREIT (2009). Frequently Asked Questions About REITs.[online version] ] [cit. 2009-01-24]. Available on: http:// www.reit.com/AllAboutREITs/REITFAQs/tabid/63/Default. aspx

[3] Adamuscin, A. (2008). Real Estate Investment Trust (REIT). Juniorstav 2008, Brno. [Online version] ] [Cit. 2009-01-24]. Available on: http://www.fce.vutbr.cz/veda/juniorstav2008 sekce/pdf/5/Adamuscin_Andrej_CL.pdf (in Slovak).

[4] Internal Revenue Code Sector 856. Definition of real estate investment trust. TITLE 26, Subtitle A, CHAPTER 1, Subchapter M.

[5] Cussen, M. The Basics of REIT Taxation. Investopedia. [Online version] [Cit. 2009-01-24]. Available on: http://www. investopedia.com/articles/pf/08/reit-tax.asp

[6] Eicholtz, P. - Kok, N.(2007). The EU REIT and the Internal Market for Real Estate. [Online version] [Cit. 2009-01-27].
Maastricht University. Available on: http://www.tegova.org/ en/p4912e4223ab63

[7] Ivanicka, K. (2008): Európske realitné investičné trusty $v$ Európe (European real estate investment trusts in Europe). STU Bratislava. STU Conference. (In Slovak).

[8] Ivanicka, K. - Adamuscin, A. (2008): Európske realitné investičné trusty (European real estate investment trusts in Europe). [PowerPoint slides]. STU Conference 2008.

[9] KPMG (2008). Introduction of the Real Estate Investment Trust (REIT) in Germany [Online version] [Cit. 2009-01-24]. Available on: http://kpmg.de/docs/20080601_Introduction of_the_Real_Estate_Investment_Trust_(REIT)_in_Germany. pdf

[10] Adamuscin, A. (2008). Špeciálne podielové fondy nehnutel'ností. (Special Real Estate Funds). Nehnutel'nosti a bývanie 3, 2, ISSN 1336-944X, pp. 32-43 (in Slovak)

[11] Zákon o kolektívnom investovaní (Collective Investment Act) č. 594/2003 Z. z.; §73a - §73j. [Online version] [Cit. 2008-10-18]. Available on: http://www.nbs.sk/ZAKLNBS/ LEGISLAT/Z5942003.PDF (in Slovak). 